\title{
Evidence-Based Complementary Medicine in Breast Cancer Therapy
}

\author{
Josef Beuth \\ Institute for Naturopathy, University of Cologne, Germany
}

\section{Key Words \\ Breast cancer - Complementary medicine . \\ Evidence-based medicine - Quality of life - Quackery}

\section{Summary}

Complementary medicine is currently widely debated by the oncologic community, because the required scientific proof of safety and effectiveness for most of the therapeutic approaches has not yet been met with definite results. In the past years, basic research and clinical evaluation of defined complementary therapeutic concepts in oncology have been intensified in an attempt to integrate these procedures into evidence-based medicine. According to definition, scientifically-based therapies of complementary medicine cannot replace the well-studied conventional cancer-destructive therapies such as surgery, chemotherapy, radiotherapy, or hormone therapy. Complementary approaches in oncology that are recommended as an addition to standard cancer-destructive therapies claim to optimize this therapy. A great body of data emerging from scientifically sound clinical trials prove that defined complementary procedures are beneficial for the patients.

\section{Introduction}

Breast cancer diseases demand diagnostic and therapeutic measures with proven quality, safety, and efficacy [1-3]. The basis for evaluation are clinical studies representing level I (randomized controlled trials, RCTs) or level II (epidemiological cohort studies) in accordance to recommendations of

\author{
Schlüsselwörter \\ Mammakarzinom · Komplementärmedizin · Evidenz- \\ basierte Medizin · Lebensqualität · Außenseitermethoden
}

\section{Zusammenfassung}

Die Anwendung komplementärmedizinischer Verfahren wird derzeit innerhalb der onkologischen Gemeinschaft stark debattiert, da wissenschaftlich fundierte Untersuchungen/Studien zur Unbedenklichkeit bzw. Wirksamkeit für die meisten Verfahren fehlen. In den vergangenen Jahren sind sowohl die Grundlagenforschung als auch die klinische Evaluation definierter komplementärmedizinischer Konzepte in der Onkologie intensiviert worden, in dem Bestreben, diese Methoden in die evidenzbasierte Medizin zu integrieren. Per Definition können auch wissenschaftlich fundierte komplementärmedizinische Therapien etablierte konventionelle Antikrebstherapien wie Chirurgie, Chemotherapie, Radiotherapie oder Hormontherapie nicht ersetzen. Komplementäre onkologische Ansätze, die ergänzend zu standardisierten Antikrebstherapien empfohlen werden, erheben den Anspruch, diese Therapien optimieren zu können. Eine Vielzahl von Daten aus relevanten klinischen Studien belegen einen Benefit definierter komplementärmedizinischer Maßnahmen für Krebspatienten.

the Centre for Evidence-Based Medicine, University of Oxford, UK [4]. Evidence-based treatment of breast cancer follows recommendations of international expert panels. They are regularly updated during conferences in St. Gallen, Switzerland, San Antonio, USA, and in Germany by the AGO Breast Commission, and comprise indication-based surgery, chemotherapy (CT), radiotherapy (RT), hormone and anti-

\begin{tabular}{ll}
\hline KARGER & ( ) 2009 S. Karger GmbH, Freiburg \\
Fax +497614520714 & Accessible online at: \\
Information@Karger.de & www.karger.com/brc \\
www.karger.com &
\end{tabular}


body therapy [5-7]. Only these therapies have proven cancerdestructive potencies and curative feasibility. Complementary therapies are recommended to support and optimize the scientifically-based cancer standard treatment.

Complementary medicine should primarily be regarded as an addition or optimization of current standard treatment options in oncology [8]. It should be differentiated from 'alternative medicine' which claims to be a replacement of evidence-based standard therapies. Although complementary and alternative medicines are grouped together in the popular acronym 'CAM', they are in fact totally different in their aims. Since many alternative treatments are still poorly documented, equating the two could lead to a misguided and undeserved rejection of complementary medicine. Complementary medicine is very popular all over the world. Especially young, female, educated, and higher socioeconomic class patients show an interest in methods that may optimize the standard treatment and protect quality of life [9].

The American Cancer Society defines complementary medicine or methods as those that are used along with regular medical care [10]. If these treatments are carefully chosen and managed, they may add to enhanced comfort and well-being [8-10]. Some complementary treatments have been tested, e.g. nutrition, sports, psycho-oncology [11], while others have not. Certain complementary medications such as sodium selenite, proteolytic enzymes, and standardized mistletoe extracts have shown clinical benefit in evidence-based medicine (EBM) level I and II trials, e.g. reduced adverse reactions of CT and RT, or enhanced quality of life $[8,11]$, while others, e.g. Lens culinaris lectin, are traditional naturopathic remedies that stabilize the mucosal surfaces [12]. Biometrically secured data for complementary medications, either from randomized controlled trials (RCTs, EBM level I) or from epidemiological cohort studies according to good epidemiological practice (GEP, EBM level II), were the basis for recommendations integrated in the education program of the Disease Management Program (DMP) Breast Cancer of the Medical Association Nordrhein in Germany.

\section{Nutrition}

The National Cancer Institute (NCI) of the United States attributes about $35 \%$ of all types of cancer to malnutrition [13]. The potential for prevention of cancer is thus large, and general nutrition guidelines for primary and secondary prevention are of much value, according to the German Society of Nutrition (DGE) and the International Society for Nutrition and Cancer [14].

It is striking to see that both fruit and vegetables play a prominent role in the prevention of cancer. For almost every type of cancer, there is evidence of protective nutritional factors. Among the cancer-promoting factors, obesity plays a major role in addition to smoking and alcohol. The role of animal fats as a carcinogenic factor remains unclear. Although fats are considered to increase the risk of (breast)cancer, there is neither compelling evidence from epidemiological studies nor any other indication for a causal relationship. This statement does not address the role of fats as energy source or their possible role in the development of obesity $[8,15]$.

Once cancer becomes apparent, success of therapy or the healing process are decisively determined by the patient's nutritional state. Fundamentally, a specific advisory for the patient's optimized nutrition is of great importance at this point, since malnutrition and cachexia can have a significant effect on the quality and duration of life. Malnutrition increases cancer mortality by about $30 \%[15,16]$, and cachexia worsens the prognosis of disease significantly since it is associated with reduced response to treatment, more complications and adverse reactions of the treatment, and prolonged hospitalization. Socalled 'cancer diets' (e.g. Gerson, Budwig, Breuss, TKTL-1 diet) have not yet shown any scientifically sound benefit for patients, however, they bear the risk of delaying curative treatment options and of inducing life-threatening malnutrition. Accordingly, they cannot be recommended to cancer patients [17].

\section{Exercise - Physical Activity}

Exercise in the form of 'moderate endurance training' (e.g. walking, jogging, swimming, cycling; all under strict aerobic conditions) and 'focused gymnastics' (e.g. stretching, functional, water, and spinal column gymnastics) have proved to be beneficial in the prevention and follow-up of breast cancer [18] as well as during cancer-destructive therapy [19, 20]. Cancer imposes an enormous psychological and physical stress on those afflicted, weakening the immune, hormone, and other metabolic systems [21]. Exercise, in contrast, ensures a certain tolerance to stress, which can be developed particularly through endurance training. Diagnosis and therapy of cancer exert a maximum of stress that is processed in a variety of ways. Stress entails an adaptation syndrome of neurovegetative and psycho-immunological regulatory circuits as a result of an acute or chronic challenge to the physical and psychological capabilities of the afflicted person. The patient can be trained to adapt to this burden by means of a coping strategy which includes physical activity.

Endurance exercise induces stress resistance and has beneficial effects on the psyche, thereby strengthening immune defense, the cardiovascular system, hormonal balance, and the metabolic system. Recently published clinical studies (RCTs representing level I of the EBM classification) documented beneficial effects of moderate endurance exercises for breast cancer patients during standard therapies, significantly reducing frequency and severity of fatigue syndrome and other therapy-related adverse reactions [19, 20], and during the follow-up period, enhancing quality of life $[22,23]$. 


\section{Psycho-Oncological Support}

Psychotherapeutic measures should be an integral part of any acute treatment or rehabilitation of breast cancer patients. It is widely known that handicaps may lead to psychosomatic diseases and that these can be relieved or even cured with appropriate psychological aid or therapeutic modalities. In addition, psychotherapeutic measures are indicated for dealing with disease in the following types of problems or symptoms: emotional disturbances such as fear or depression; conflicts within a relationship or family; impairment in social behavior; social withdrawal tendencies; psychological impairment with physical decline or deterioration; problems accepting the disease; discrepancies between therapeutic expectancy and actual treatment options; inadequate behavior towards the disease.

Psychotherapy is an integral part of acute and rehabilitative treatment in oncology, and it has proved its beneficial effects, such as improvement of quality of life, especially for breast cancer patients in well-designed RCTs and meta-analyses [24, 25]. Psycho-oncological treatment options (e.g. visualization, relaxation, creativity training, discourse) should be recommended individually and were recently published [21]. However, psycho-oncological support has not been shown to enhance disease-free and overall survival of breast cancer patients in clinical studies. RCTs are urgently warranted to demonstrate these effects and are currently under investigation.

\section{Selenium}

Selenium is an essential trace element recognized as a cancerprotective agent, and it is increasingly administered in complementary cancer therapy. Whereas for cancer prevention, organic nutritional forms of selenium are used, sodium selenite is the preferred form of selenium for therapeutic applications. Sodium selenite is mainly administered complementarily to reduce side effects of CT and RT. Patients are typically treated with $300 \mu \mathrm{g}$ sodium selenite/day orally or by infusion for 1-5 days prior to and during CT and RT, and subsequently with oral doses of 100-150 $\mu \mathrm{g} /$ day as needed for maintenance. Sodium selenite is also used complementarily with biological therapies and in the management of secondary or postoperative lymphedema [26-28].

Experimental in vitro data showed that sodium selenite can enhance the efficacy of CT and RT [29, 30]. Since the molecular basis of the mode of action of sodium selenite was demonstrated in detail [8], discussions regarding its potency to inhibit standard therapies have stopped. RCTs have demonstrated benefits for cancer patients receiving sodium selenite during CT and RT, e.g. reduction of lymphedema in head and neck and breast cancer patients [26-28, 31]. In 2007, the German Society of Radiooncology (DEGRO) gave an award to a clini- cal trial on complementary sodium selenite administration in gynecologic radiation oncology, since it significantly improved quality of life [31].

\section{Proteolytic Enzymes}

Significant reduction of disease- and therapy-induced symptoms, such as nausea, vomiting, cachexia, or mucosal ulceration, in cancer patients treated with $\mathrm{CT}$ and RT was achieved with a standardized combination of proteolytic enzymes (papain, trypsin, and chymotrypsin). Depending on the type and stage of cancer, quality of life was significantly improved in breast and colorectal cancer and plasmocytoma patients whereas relapse-free survival was significantly prolonged only in plasmocytoma patients complementarily treated with proteolytic enzymes [32-34].

As EBM-relevant cohort studies (level II) have shown that complementary treatment of patients with breast cancer and other tumor entities with proteolytic enzymes improved quality of life and enhanced the efficacy of standard therapies, it was designated orphan drug status by the FDA for the indication plasmocytoma [35].

\section{Selenium-Enzyme-Lectin Combination}

An observational trial was recently performed at the Institute of Naturopathy at the University of Cologne to evaluate the benefit of complementary treatment with a defined combination of sodium selenite, proteolytic enzymes, and Lens culinaris lectin in breast cancer patients undergoing adjuvant CT and RT. The patients $(n=60)$ were treated according to the guidelines of St. Gallen, San Antonio, and the AGO Breast Commission ( $\mathrm{n}=30$; control group), and complementarily ( $\mathrm{n}=30$; study group) with a combination of sodium selenite (300 $\mu \mathrm{g} /$ day), proteolytic enzymes (bromelaine and papain; 4,000 FIP units/day) and Lens culinaris lectin (20 mg/day) in certified breast cancer centers. On case report formulas, selfassessment of tolerability and side effects of CT, RT, and complementary treatment, e.g. gastrointestinal tract disorders such as nausea, vomiting, mucositis, mucosal dryness, arthrotic pain, fatigue, and inflammation were documented. Validation was done by scoring from 1 (no side effects/optimal tolerability) to 6 (extreme side effects/extremely bad tolerability). Compared to the control group (mean score: 3.8 CT; 3.4 RT), the tolerability of the adjuvant treatment was better in the study group (mean score: 1.8 CT; 1.5 RT). It was shown that enhanced tolerability of adjuvant CT and RT resulted from reduced side effects, especially nausea (mean score: 3.1 control; 1.8 study), mucositis (mean score: 2.9 control; 1.3 study), and arthrotic pain (mean score: 3.6 control; 1.2 study). No adverse reactions of the complementary treatment were documented, confirming the data from the literature. 
This observational trial demonstrates benefits of indicationbased complementary treatment in breast cancer patients, e.g. reduction of side effects and enhancement of tolerability of adjuvant CT and RT. An RCT confirming these clinical findings is currently planned to integrate the complementary treatment with the combination of sodium selenite, proteolytic enzymes, and Lens culinaris lectin into EBM.

\section{Balanced Vitamin/Trace Element Mixtures}

Cancer patients have an increased requirement for essential micronutrients that are rarely adequately supplied even through a wholesome and balanced diet. This holds especially true before or during cancer-destructive therapy, since the need for micronutrients in these phases is increased due to side effects such as reduced appetite, nausea, vomiting, diarrhea, and perspiration [36]. It has been demonstrated that a deficit in micronutrients (vitamins, trace elements, minerals) results in a reduced tolerance of current standard cancer therapy [37].

The role of micronutrients in the primary and secondary prevention of cancer is multifunctional. Vitamins, trace elements, and minerals inhibit the activation of cancer-causing substances as well as inflammatory processes. Other micronutrients can prevent the re-uptake of cancer-inducing substances into the cell and protect cellular DNA by disabling the adhesion of cancerous compounds [38].

Indication-dependent supplementation with micronutrients (combination of balanced vitamins, trace elements, and minerals) according to the recommended daily allowances recommended by the DGE or the International Society for Nutrition and Cancer for the prevention of cancer or for the compensation of therapy-induced nutritive deficits has proved to be beneficial in intervention studies and controlled clinical trials $[37,38]$.

\section{Mistletoe Extract}

Standardized mistletoe extracts have been applied to cancer patients for several decades as complementary medications [39]. They were introduced into oncological treatment by Steiner around 1920, and there are many reports on their clinical efficacy [40]. However, the evidence of these results is still controversial since the problem of adequate methodology in testing safety and efficacy of complementary medicine is still a matter for discussion.

Mistletoe extracts with defined amounts of mistletoe lectinI (ML-I) yielded promising experimental and clinical results [41-43]. Recent research showed that the same can be found with standardized mistletoe extracts with a predominant content of ML-III [39, 40, 44]. Initial clinical studies of EBM levels I and II have shown that complementary application of standardized mistletoe extract can reduce side effects of chemotherapy and improve quality of life in breast cancer patients [41-44]. However, further studies of adequate methodology are urgently needed to definitively prove this clinical benefit.

This conclusion was recently confirmed by the Cochrane Database of Systematic Reviews 2008: 'There is evidence that mistletoe extracts may offer benefits on measures of quality of life during chemotherapy for breast cancer, but these results need replication. Overall, more high quality, independent clinical research is needed to truly assess the safety and effectiveness of mistletoe extracts. Patients receiving mistletoe therapy should be encouraged to take part in future trails' [45].

Following the recommendation of the responsible German Health Authority (Gemeinsamer Bundesausschuss, GemBA), administration of standardized mistletoe extract is evidencebased to improve the quality of life in palliative care [46]. There are scientifically sound clinical studies that prove significant benefits for patients with advanced cancers, which were the basis for the positive validation of the GemBA.

\section{Quackery}

It is imperative to beware of non-safety- and non-efficacyproven diagnostic and therapeutic approaches which are sometimes erroneously associated with complementary medicine. Non-evaluated diagnostic and therapeutic measures are extensively advertised and wrongly suggest after application: inhibition of cancer growth and reduction of cancer mass; prolongation of relapse-free and metastasis-free survival; prolongation of overall survival; intensified effectiveness of CT and RT; delay of the necessity of CT or RT; cure even if all standard options have failed. Although innovative concepts are appreciated, therapeutic procedures not based on sound scientific principles may ultimately be life-threatening for cancer patients since they may delay curative treatment options [47].

\section{References}

1 Kreienberg R, Jonat W, Volm T, Moebus V, Alt D: Management des Mammakarzinoms. Hamburg, Springer Verlag, 2006.

2 De Vita VT, Hellman S, Rosenberg SA: Cancer Principles and Practices of Oncology, 6th ed. Philadelphia, Lippincott Williams and Wilkins, 2001.
3 Kaelin CM: Living through Breast Cancer. New York, McGraw Hill, 2005.

4 Sackett DL, Rosenberg WMC, Gray JAM, Heynes RB, Richardson WS: Evidence-based medicine: what it is and what it isn't. Br Med J 1996;312:71-72.
5 Harbeck N, Jakesz R: St. Gallen 2007: breast cancer treatment consensus results. Breast Care 2007;2: 130-134.

6 29th Annual San Antonio breast cancer symposium 2006. Breast Cancer Res Treat 2006;103:115-124. 
7 AGO Breast Commission: Diagnosis and treatment of patients with primary and metastatic breast cancer. Guidelines of the AGO Breast Commission, 2008. www.ago-online.org/index.php?site $=$ mamma_ guide\&lang_de.

8 Beuth J, Moss RW: Complementary Oncology: Adjunctive Methods in the Treatment of Cancer. New York, Thieme, 2005.

9 Unger C, Weis J: Unkonventionelle und supportive Therapiestrategien. Stuttgart, Wissenschaftliche Verlagsgesellschaft, 2006.

10 American Cancer Society: Guidelines for using complementary and alternative medicine, 2008. www.cancer.org.

11 Beuth J, Schierholz JM: Evidence-based complementary oncology. Innovative strategies to optimize standard therapy strategies. In Vivo 2007;21 423-428.

12 Vecchi M, Torgano G, de Franchis S: Evidence of altered structural and glycoconjugates in the jejunal mucosa of patients with gluten sensitive enteropathy and subtotal villus atrophy. Gut 1989;30:804-810.

13 Doll R, Peto R: The causes of cancer. Quantitative estimates of avoidable risks of cancer in the United States today. J Natl Cancer Inst 1981;66:1193-1208.

14 Prasad KN, Cole WC: Cancer and Nutrition. Amsterdam, IOS Press, 1998.

15 Zuercher G: Tumoren; in Kluthe R (ed): Ernaehrungsmedizin in der Praxis: Aktuelles Handbuch zur Prophylaxe und Therapie ernährungsabhängiger Erkrankungen. Balingen, Spitta, 2001.

16 Stiefelhagen P: Ernaehrung und Krebs - Was ist gesichert? Dt Z Onkol 2006;38:35-39.

17 Zuercher G: Krebsdiäten. Forum DKG 2006;4: 49-51.

18 Landessportbund NRW: Sport in der Krebsnachsorge. Duisburg, Landessportbund NRW, 2005

19 Holmes MD, Chen WY, Freskanich D, Kroenke $\mathrm{CH}$, Colditz GA: Physical activity and survival of breast cancer diagnosis. JAMA 2005;293:2479-2486.

-20 Meyerhardt JA, Heseltine D, Niedzwiecki D, Hollis D, Saltz LB, Thomas J, Nelson H, Whithorn R, Hantel A, Schilsky RL, Fuchs CS: The impact of physical activity on cancer recurrence and survival in patients with stage III colon cancer. Findings from Intergroup trial CALBG 89803. J Clin Oncol 2006;23:3535-3541.

21 Tschuschke V: Psychoonkologie. Stuttgart, Schattauer, 2005.

22 Schulz T, Peters C, Michna H: Bewegungstherapie und Sport in der Krebstherapie und -nachsorge. Deutsche Zeitschrift für Onkologie 2005;37:159 168
23 Schuele K: Bewegung und Sport in der Krebsnachsorge. Forum DKG 2001;2:39-41.

24 Spiegel D, Classen C: Group therapy for cancer patients. Basic behavorial science. New York, Basic Books, 2000.

25 Rehse B: Metaanalytische Untersuchungen zur Lebensqualität adjuvant psychoonkologisch betreuter Krebsbetroffener. Aachen, Shaker, 2001

26 Bruns F, Buentzel J, Mucke R, Schoenekaes K, Kisters K, Micke O: Selenium in the treatment of head and neck lymphedema. Med Print Pract 2004;13:185-190.

27 Zimmermann T, Leonhardt H, Kersting S, Albrecht S, Range U, Eckelt U: Reduction of postoperative lymphedema after oral tumor surgery with sodium selenite. Biol Trace Elem Res 2005;106:193-203.

28 Kasseroller RG, Schrauzer GN: Treatment of secondary lymphedema of the arm with physical decongestive therapy and sodium selenite. Am J Ther 2000;7:273-279.

29 Hehr T, Bamberg M, Rodemann HP: Praeklinische und klinische Relevanz der radioprotektiven Wirkung von Natriumselenit. InFo Onkol 1999;S2: 25-29.

30 Roth T, Fiebig HH: Cytotoxic profile of sodium selenite (Selenase) and sodium selenite in combination with clinically used chemotherapeutic agents in human tumor models. InFo Onkol 1999;S2:30-39.

31 Muecke R: Sodium selenite in gynaecologic radiation therapy. Results of a prospective randomized observation study. Trace Elem Electrolytes 2006;23:173-177.

32 Popiela T, Kulig J, Hanisch J, Bock PR: Influence of complementary treatment with oral enzymes on patients with colorectal cancers: an epidemiological retrolective cohort study. Cancer Chemother Pharmacol 2001;S47:55-63.

33 Sakalova H, Bock PR, Dedik L, Hanisch J, Schiess W, Gazova S, Chabranova I, Holomanova D, Mistrik M, Hrubisko M: Retrolective cohort study of an additive therapy with an oral enzyme preparation in patients with multiple myeloma. Cancer Chemother Pharmacol 2001;S47:38-41.

34 Beuth J, Ost B, Pakdaman A, Rethfeldt E, Bock PR, Hanisch J, Schneider B: Impact of complementary enzyme application on the postoperative treatment results of breast cancer patients. Results of an epidemiological multicenter cohort study. Cancer Chemother Pharmacol 2001;S47:38-44.

35 Beuth J: Proteolytic enzyme therapy in evidencebased complementary oncology. Fact or fiction? Int Cancer Ther, 2008;7:311-316.
36 Groeber U: Mikronährstoffe. Stuttgart, Wissenschaftliche Verlagsgesellschaft, 2006.

37 Prasad KN, Cole WC, Kumar B, Prasad KC: Scientific rationale for using high dose multiple micronutrients as an adjunct to standard and experimental cancer therapies. Am J Coll Nutr 2001;20:450-463.

38 Biesalski HK: Antioxidative Vitamine in der Prävention. Dt Ärzteblatt 1995;92:1316-1321.

39 Büssing A: Biological and pharmaceutical properties of viscum album; in Büssing A (ed): Mistletoe. The Genus Viscum. Newark, NJ, Harwood Academic Publishers 2000, pp. 123-182.

40 Kienle GS, Berrino F, Buessing A, Portalupi E, Rosenzweig S, Kiene H: Mistletoe in cancer. A systematic review on controlled clinical trials. Europ J Med Res 2003;8:109-119.

41 Semiglasov VF, Stepula VV, Dudov A, Lehmacher W, Mengs U: The standardized mistletoe extract PS76A2 improves quality of life in patients with breast cancer receiving CMF chemotherapy: a randomized, placebo-controlled, double-blind, multicentre clinical trial. Anticancer Res 2004;24:12931302.

42 Semiglasov VF, Stepula VV, Dudov A, Schnitker J, Mengs U: Quality of life is improved in breast cancer patients by standardised mistletoe extract PS76A2 during chemotherapy and follow-up: a randomised, placebo-controlled, double-blind, multicentre clinical trial. Anticancer Res 2006;26:1519 1529

43 Schumacher K, Schneider B, Reich G, Stiefel T, Stoll G, Bock PR, Hanisch J, Beuth J: Influence of postoperative complementary treatment with lectin-standardized mistletoe extract on breast cancer patients. A controlled epidemiological multicentric retrolective cohort study. Anticancer Res 2003;23:5081-5087.

44 Piao BK, Wang XY, Xie GR, Mannsmann U, Matthes H, Beuth J, Lin HS: Impact of complementary mistletoe extract treatment on quality of life in breast, ovarian and non-small cell lung cancer patients. A prospective randomized controlled clinical trial. Anticancer Res 2004;24:303-310.

45 Horneber MA, Bueschel G, Huber R, Linde K, Rostock M: Mistletoe therapy in oncology. Cochrane Database Syst Rev 2008;2:CD003297.

46 Gemeinsamer Bundesausschuss: Verordnung von Arzneimitteln in der vertragsärztlichen Verordnung (Arzneimittel Richtlinie; AMR). Bundesanzeiger 2004;155:11.

47 Münstedt K: Ratgeber unkonventionelle Krebstherapien. Landsberg, ecomed, 2005. 